\title{
Вклад Г.Х. Рабиновича в изучение истории буржуазии дореволюционной Сибири
}

\author{
В.А. Скубневский', О.Г. Климова ${ }^{2}$ \\ ${ }^{1}$ Алтайский государственный университет (Барнаул, Россия) \\ ${ }^{2}$ Алтайский государственный технический университет им. И.И. Ползунова \\ (Барнаул, Россия)
}

\section{G.Kh. Rabinovich's Contribution to the Study of the Bourgeoisie History in Prerevolutionary Siberia}

\author{
V.A. Skubnevsky ${ }^{l}$, O.G. Klimova ${ }^{2}$ \\ ${ }^{1}$ Altai State University (Barnaul, Russia) \\ ${ }^{2}$ Altai State Technical University (Barnaul, Russia)
}

Исследованию истории регионального предпринимательства посвящено много работ сибирских историков. При изучении историографического освоения проблематики весьма важным видится обращение к персоналиям ученых, внесших наиболее существенный вклад в развитие темы. Одной из наиболее значимых фигур советских историков, посвятивших свое научное творчество истории буржуазии в дореволюционной Сибири, является Григорий Хацкельевич Рабинович. По изучению истории буржуазии ученым проделан большой путь, и сегодня можно констатировать многочисленные публикации, их жанровое многообразие, огромное увеличение источниковой базы и документов. Г.Х. Рабиновичем опубликовано более 50 научных работ. Для трудов историка характерны широкий охват проблематик исследования, изучение исторических процессов на основе богатого архивного материала, включение сибирской истории в контекст российской и мировой. Предложенные профессором принципы и структурные компоненты анализа буржуазии в настоящее время считаются общепринятыми. Серьезное исследование предпринимательства Сибири началось именно с его творчества, значение которого еще не до конца оценено. Выводы исследователя получили дальнейшее развитие в трудах современных историков Сибири. Тематика проблем, связанных с изучением истории предпринимательства буржуазии, позволяет утверждать, что научное наследие Г.Х. Рабиновича можно отнести к несомненным достижениям сибирской историографии третьей четверти XX в.

Ключевые слова: история буржуазии, предпринимательство, историография, Сибирь, научная школа.
Many papers of Siberian historians are devoted to the study of the history of regional entrepreneurship. When studying the historiographical development of the problems, it is very important to appeal to the personalities of the scientists who have made the most significant contribution to the development of the topic.

One of the most significant figures of Soviet historians who devoted their scientific work to the history of the bourgeoisie in pre-revolutionary Siberia is Gregory Khatskelevich Rabinovich. Scientists have come a long way to study the history of the bourgeoisie, and today we can find numerous publications, their genre diversity, a huge increase in the source base and documents. G.K. Rabinovich published more than 50 scientific papers. The works of the historian are characterized by a wide scope of research issues, the study of historical processes based on rich archival material, the inclusion of Siberian history in the context of Russia and world. The principles and structural components of the analysis of the bourgeoisie proposed by the professor are now generally accepted. A serious study of entrepreneurship in Siberia began precisely with his work, the significance of which is not fully appreciated yet. The findings of the researcher were further developed in the writings of modern historians of Siberia. The topics of problems related to the study of the history of bourgeois entrepreneurship suggest that the scientific heritage of G.K. Rabinovich should be attributed to the undoubted achievements of the Siberian historiography of the third quarter of the $20^{\text {th }}$ century.

Key words: history of bourgeoisie, entrepreneurship, historiography, Siberia, scientific school.

DOI 10.14258/izvasu(2019)5-13 
В настоящее время одним из приоритетных направлений отечественной историографии стала история российского, в том числе сибирского, предпринимательства. История предпринимательства как научное направление в отечественной историографии длительное время была посвящена изучению буржуазии, и только в последние десятилетия стала развиваться как история предпринимательства и купечества. В разные исторические периоды проблема взаимоотношений российского государства и капитала являлась объектом внимания и изучения ученых. В 1960-1970-е гг. сибирские историки впервые обратились к изучению проблем буржуазии, ввели в историографию довольно много новых материалов и определили ряд интересных проблематик.

Очевидно, что сегодня можно говорить о том, что история предпринимательства прочно утвердилась на историографическом поле, а достигнутые результаты нуждаются в осмыслении и подведении некоторых итогов. А поэтому актуальной становится проблематика, связанная с изучением научных трудов персоналий - ученых, чьи интересы посвящены проблемам истории предпринимательства в дореволюционной Сибири.

Цель работы - рассмотреть научное творчество известного ученого, доктора исторических наук, профессора Григория Хацкельевича Рабиновича (1934-1981), который является одной из крупнейших фигур в сибиреведении второй половины ХХ в.

Г.Х. Рабинович родился 4 октября 1934 г. в Красноярске. В 1952 г. после окончания школы будущий историк стал студентом историко-филологического факультета Красноярского педагогического института. С 1956 по 1962 г. после окончания вуза он преподавал историю в Красноярской школе МВД, в школе рабочей молодежи, потом в кооперативном техникуме. В 1962 г. Г.Х. Рабинович стал аспирантом Томского государственного университета [1, с. 330-333]. В поле зрения молодого ученого оказались сюжеты, связанные с изучением промышленности Енисейской губернии конца XIX - начала XX в. [2], положения и численности рабочих золотопромышленности Сибири [3] и др. В своей работе «Технический переворот и его финансирование в золотопромышленности Енисейской губернии в конце XIX - начале XX в.» автор впервые исследовал причины кризиса и упадка золотопромышленности, проникновение иностранного капитала и его роль в техническом перевороте Сибири [4]. Им было замечено, что промышленный переворот в золотопромышленности Енисейской губернии завершился в начале XX в., а предприятия Сибири в эпоху империализма являлись типичными заведениями мануфактурного типа.

Постепенное осмысление выбранного научного направления определило тему диссерта- ционного исследования. В 1964 г. Г.Х. Рабинович успешно защитил кандидатскую диссертацию «Золотопромышленность Енисейской губернии в конце XIX — начале XX вв.» под руководством доцента А.П. Бородавкина. Кандидатская диссертация стала первой комплексной работой, в которой историк исследовал динамику золотодобычи, социально-экономические отношения, соотношение мануфактурного и машинного производства, рабочее движение, а также численный и социальный состав золотопромышленников, различные виды капиталов. Им были введены в научный оборот ранее не использовавшиеся документы из личных и семейных архивов предпринимателей, материалы из фондов окружных судов, судебных палат, частных банков. Отметим, что с этого периода формируется внимательное отношение историка к проблеме источникового обеспечения исследований, к изучению документов.

Выводы, полученные в диссертационной работе, накопленный архивный и другой эмпирический материал позволили расширить научную проблематику, поставить более широкие научные задачи. Г.Х. Рабинович занялся изучением истории буржуазии Сибири. Григорий Хацкельевич в своих исследованиях охватывает большой круг проблем. Это и определение численности, и формирование, и сферы деятельности, и происхождение, и общественное положение буржуазии. Им был исследован социальный аспект промышленного переворота. Также объектом исследования историка стало развитие крупной обрабатывающей промышленности, речного транспорта и др.

Работы ученого хронологически охватывают преимущественно период конца XIX - начала XX в. В своих трудах Г.Х. Рабинович много цитирует классиков марксизма, что тогда было данью времени. Так, например, он пишет: «Чтобы бороться с классовым врагом, надо его знать» [5, с. 70], «Изучение российской буржуазии позволяет лучше понять расстановку классовых сил в стране» [6, с. 1]. Как отмечает В.П. Зиновьев, «определить степень зрелости капитализма без знания истории буржуазии было никак нельзя» [7, с. 19].

По мнению В.П. Бойко, «начало широкого и комплексного изучения сибирского предпринимательства связано с именем Г.Х. Рабиновича» [8, с. 206]. Следует отметить, что историк в своих работах фактически касался тем торговли и предпринимательства значительно раньше, когда они еще не разрабатывалась в историографии, хотя и не обозначал их в названиях своих работ.

Глубоко и всесторонне Г.Х. Рабиновичем проанализирована торговля середины XIX - начала XX в. Изучая предпринимательскую деятельность буржуазии Сибири, автор показал картину торго- 
вой деятельности крупнейших фирм - Бутиных, Второвых, Гадаловых, Жернаковых, Коковина и Басова, Кухтериных и многих других. Так, он пишет: «В Сибири торговая буржуазия вплоть до 1917 г. была наиболее многочисленным и экономически сильным слоем этого класса. Из среды сибирских купцов-торговцев "выросли" некоторые крупнейшие предприниматели всероссийского масштаба» [9, с. 253]. По мнению Г.Х. Рабиновича, для сибирских капиталистов было характерно переплетение различных форм предпринимательства: фабричного, торгового, ростовщического, так как это повышало прибыль.

Обращаясь к содержанию понятия «октябристский капитал», он исследует предпринимательскую деятельность отдельных представителей буржуазии. Например, изучает историю одного из лидеров октябристской партии, владельца механического завода в Москве и Судженских каменноугольных копий в Кузбассе дворянина Л.А. Михельсона, историю накопления капиталов сибирскими купцами Второвыми. По мнению ученого, «большая часть торгово-ростовщической и торгово-промышленной буржуазии периферии выступала посредником между банковскими монополиями и мелкими товаропроизводителями (крестьянами и ремесленниками) в этих районах» $[10$, с. 39]. Им подробно показана торговля Томска, Барнаула, Новониколаевска, городов Забайкалья. А также специфика сибирской торговли до и после проведения Сибирской железной дороги.

Так, в соавторстве с Л.А. Солопий была опубликована работа по истории крупной буржуазии Забайкалья, в которой авторы сосредоточили внимание на таких вопросах, как численность и состав буржуазии, источники и пути ее формирования, методы формирования капиталов. По мнению историков, «в целом в Забайкалье имели место два пути формирования буржуазии - "сверху" и "снизу". Ведущим был процесс формирования крупной буржуазии "снизу" из числа верхушки мещан и, в меньшей степени, крестьян и казаков (2/3 всех предпринимателей). Следует учитывать, что значительная часть мещан городов Забайкалья вышла из крестьянского сословия» [11, с. 202].

Созданная Г.Х. Рабиновичем научная школа получила свое дальнейшее воплощение в творческой деятельности В.А. Скубневского, одного из авторов настоящей статьи. Этими двумя историками было опубликовало несколько совместных работ по истории сибирской буржуазии.

Так, в статье «Буржуазия в обрабатывающей промышленности Сибири (конец XIX в. 1917 г.)» было рассмотрено «крупнокапиталистическое предпринимательство» в обрабатывающей промышленности Сибири после проведения Сибирской железной дороги, специфика генезиса фабричной буржуазии, численность и состав капиталистов-фабрикантов, организационные формы производства и капитала. Был дан анализ отраслей промышленности, где «развертывалось предпринимательство этих капиталистов», - металлургической, металлообрабатывающей, деревообрабатывающей, спичечной, мукомольной, винокуренной, кожевенной, овчинно-шубной, пимокатной, текстильной, мясоперерабатывающей, стекольной и фарфоровой, полиграфической.

Этими же авторами совместно написаны две большие статьи об истории буржуазии Барнаула «Буржуазия города Барнаула (1861 - середина 90-х годов XIX в.) [5] и «Буржуазия города Барнаула (середина 90-х годов XIX в. - 1914 г.) [13]. В работах на основе различных, главным образом архивных, источников были исследованы формирование и состав крупной буржуазии одного из важных центров Западной Сибири - Барнаула в период второй половины XIX - начала XX в. Основное внимание в статьях уделяется социально-экономическим отношениям. Позднее было отмечено, что «благодаря введению в оборот новых источников к настоящему времени уточнилось представление о развитии фабрично-заводского производства в пореформенной Сибири, в том числе и в городах» $[14$, с. 89$]$.

Проблематика исследований профессора Г.Х. Рабиновича многообразна. Так, монополизации речного судоходства в Сибири и на Дальнем Востоке посвящена большая статья ученого, в которой он определил роли различных территориальных групп буржуазии в этом процессе [15]. Историк показал, что первые монополистические соглашения амурских пароходовладельцев были заключены во второй половине XIX в. В это же время, по его мнению, к востоку от Байкала сохранялись монополии старокупеческого типа, основанные на отсутствии конкуренции и правительственных привилегий.

Исследователь обращается и к совершенно не изученному вопросу - городской недвижимости как сфере приложения капиталов. Он определил сумму вложений в недвижимость в крупнейших городах Сибири и Дальнего Востока. В статье содержатся яркие характеристики владельцев городской недвижимости (Я. Семенова, В. Бабинцева и др.), которые извлекали из нее «огромные прибыли», в то время «когда основная масса населения жила в коморках грязных городских предместий, снимая квартиры в подвалах и чердаках за непомерно высокую плату» [16, с. 125].

Важно отметить, что 1970-е гг. стали периодом наиболее интенсивной научно-исследовательской работы Г.Х. Рабиновича. В 1975 в г. Томске он успеш- 
но защитил докторскую диссертацию «Крупная буржуазия и монополистический капитал в экономике Сибири конца XIX - начала XX вв.». Общие итоги изучения истории буржуазии Сибири исследуемого периода были подведены историком в монографии [17]. Работа написана на основе большого количества архивных материалов, многие документы были введены в научный оборот впервые.

Всего использованы материалы более 1300 единиц хранения 172 фондов 17 центральных и региональных архивов. В их числе - документы о причислении крестьян к купечеству, возведении купцов в число почетных граждан, купеческие книги в фондах городских дум и управ, ведомости торговых домов и товариществ, списки владельцев недвижимого имущества, духовные завещания (их автор обнаружил несколько сотен), личные фонды предпринимателей, в том числе таких значимых фигур, как Л.А. Михельсон, Трапезниковы, М.Д. Бутин, Ф.М. Немчинов, Г. В. Юдин.

Настоящей находкой для исследования избранной темы стали документы ряда крупных предпринимателей из сейфов петроградских банков. Г.Х. Рабинович отметил: «Ценность материалов, хранящихся в сейфах частных банков, возрастает в связи с тем, что там отложилось немало документов по истории отдельных буржуазных семей за целый ряд поколений, что дает определенный материал для изучения генезиса буржуазии» [17, с. 34].

Широко автор использовал в своих трудах, в том числе в монографии, фонды Государственного и частных коммерческих банков, в частности клиентские списки, опубликованные и архивные материалы податной инспекции, фонды ряда акционерных обществ - «Лензото», «Копикуза», «Золоторосса», общества «Драга» и др., фонды горных правлений. При исследовании предпринимательства в промышленности отбирались так называемые «карточные сведения», т.е. данные о каждом предприятии отдельно, где указывались фамилия владельца, обороты предприятия, численность рабочих, техническая оснащенность и др. В числе таких источников были, например, «Указатель фабрик и заводов окраин России: Царства Польского, Кавказа, Сибири и Средне-Азиатских владений», составленный П.А. Орловым (СПб., 1895), «Фабрично-заводские предприятия Российской империи (СПб., 1914) и др. Использование данных источников позволило выявить крупных предпринимателей в промышленности и определить владельцев фабрик и мануфактур.

К крупной буржуазии ученый отнес купцов 1-й и 2-й гильдий, на 1912 г. первогильдейцев оказалось 99, купцов 2-й гильдии - 1005, всего - 1104 человека $[17$, с. 49]. Автор подсчитал количество торговых домов и товариществ - около 100, акцио- нерных обществ (более 70), которые действовали в Сибири, их суммарный капитал был около 210 млн руб. [17, с. 327].

Г.Х. Рабинович на основе данных о происхождении 724 предпринимателей сделал подсчеты об источниках формирования крупной буржуазии Сибири: местными уроженцами были более 68 \%, из Европейской России - 29 \%, иностранцами - 1,7 \%; по сословному происхождению - из мещан и цеховых - 40,2 \%, из крестьян и казаков $25,3 \%$, из дворян и чиновников - 5,1 \%. При этом неоднократно подчеркивалось, что из крестьян Европейской России происходили многие крупнейшие предприниматели Сибири.

Впервые в историографии Г.Х. Рабинович выявил монополии в разных сферах экономики Сибири. Он пришел к выводу, что процесс монополизации в экономике Сибири шел двумя путями - внедрением промышленных и банковских монополий Европейской России и зарубежных стран и созданием местных монополий при ведущей роли первого пути. При этом процесс социально-экономического и политического созревания буржуазии был ускорен вторжением в Сибирь монополистического капитала [17, с. 325].

Значимость монографии и докторской диссертации Г.Х. Рабиновича заключается и в том, что они имели значение для оценки всего социально-экономического развития региона и уровня капиталистических отношений. Монография историка получила высокую оценку в отечественной историографии, в частности, на нее неоднократно ссылался один из крупнейших специалистов в области экономической истории России В.И. Бовыкин, он же был одним из официальных оппонентов при защите Г.Х. Рабиновичем докторской диссертации.

На изучение истории сибирской буржуазии профессор направил и усилия своих учеников. На протяжении нескольких лет он руководил работой сотрудников Проблемной научно-исследовательской лаборатории истории, археологии и этнографии Сибири при Томском государственном университете. Так, В.П. Зиновьев вспоминает: «В Проблемной лаборатории образовалась группа научных сотрудников, под руководством профессора Г.Х. Рабиновича, которая и занималась историей буржуазии в Сибири и на Дальнем Востоке, и Григорий Хацкельевич набирал для этого исследования аспирантов... Историки так называемой "Рабочей группы" также, в силу изучения промышленности и транспорта, собирали материал по истории отраслевых групп буржуазии. В.А. Скубневский и Б.К. Андрющенко - по предпринимателям в обрабатывающей промышленности, H.M. Дмитриенко - по городским капиталистам, В.Н. Большаков - по пароходчикам, я - по горнозаводским промышленникам. Обсуждения ста- 
тей, докладов проводились обыкновенно совместно всеми "капиталистами" во главе с Н.В. Блиновым и Г.Х. Рабиновичем» $[7$, с. 19, 20].

В числе учеников Г.Х. Рабиновича отметим В.П. Бойко, Л.А. Солопий, также О.Н. Разумова, который успешно занимался изучением иностранного капитала в Сибири [18].

В 1994 г. вышел в свет тематический сборник статей, посвященный памяти Г.Х. Рабиновича, в котором была опубликована его статья, характеризующая состав финансовой олигархии в России [19]. По мнению редакторов сборника (В.П. Зиновьева, О.Н. Разумова, Э.И. Черняка, В.А. Бузановой), Г.Х. Рабинович предпринял попытку, едва ли не первую в нашей историографии, определить состав финансовой олигархии в России.

В ряде статей, в том числе написанных в соавторстве с И.Г. Мосиной, Н.В. Блиновым, Г.Х. Рабинович обратился к вопросам политического формирования сибирской буржуазии. Так, Н.В. Блинов и Г.Х. Рабинович отмечали, что до Первой русской революции 1905-1907 гг. центрами представительства буржуазии были городские думы и управы, с конца XIX в. стали создаваться отраслевые представительные организации, а после создания политических партий интересы буржуазии отстаивали отделения партий октябристов и кадетов, при этом кадеты были в Сибири наиболее влиятельной из легальных партий [20, с. 124].
Г.Х. Рабиновичем опубликовано более 50 научных работ. Для трудов историка характерны широкий охват территории исследования (Сибирь, Дальний Восток, европейская часть России), изучение исторических процессов на основе богатого архивного материала, включение сибирской истории в контекст российской и мировой. Предложенные профессором принципы и структурные компоненты анализа буржуазии в настоящее время считаются общепринятыми. Конечно, выводы о промышленном перевороте, закономерной монополизации капитала, негативной сути российской буржуазии, к которым пришел в своих трудах ученый, по форме были в русле марксистского учения, но серьезное исследование предпринимательства Сибирского региона началось именно с его творчества, значение которого еще не до конца оценено.

Подводя итоги, следует отметить, что доктором исторических наук, профессором Григорием Хацкельевичем Рабиновичем был сделан большой шаг в изучении истории сибирской буржуазии. Выводы исследователя получили дальнейшее развитие в трудах современных историков Сибири. А широкий тематический охват проблем, связанных с изучением истории предпринимательства буржуазии, позволяет утверждать, что научное наследие Г.Х. Рабиновича можно отнести к несомненным достижениям сибирской историографии 1960-1970-х гг.

\section{Библиографический список}

1. Профессора Томского университета : биографический словарь. Т. 3 (1945-1980) / отв. ред. С.Ф. Фоминых. Томск, 2001.

2. Незнаева З.Ф., Рабинович Г.Х. К истории промышленности Енисейской губернии конца XIX - начала $\mathrm{XX}$ вв. (Публикация документов и комментарии). Красноярск, 1962.

3. Рабинович Г.Х. Динамика численности и состав рабочих золотопромышленности Енисейской губернии в конце XIX - начале XX в. // Из истории рабочего класса Сибири. Енисейск, 1964.

4. Рабинович Г.Х. Технический переворот и его финансирование в золотопромышленности Енисейской губернии в конце XIX - начале XX в. // К изучению экономики Енисейской губернии конца XIX - начала XX вв. Красноярск, 1962.

5. Рабинович Г.Х., Скубневский В.А. Буржуазия города Барнаула (1861 - середина 90-х годов XIX в.) // Из истории Сибири. Выпуск первый. Томск, 1970.
6. Рабинович Г.Х. Крупная буржуазия и монополистический капитал в экономике Сибири конца XIX - начала XX вв. : автореф. дис. ... д-ра ист. наук. Томск, 1975.

7. Зиновьев В.П. О Владимире Петровиче Бойко // Хозяйственное и культурное развитие Урала и Сибири в XIXXXI вв. : сборник научных трудов. Вып. 4. Томск, 2012.

8. Бойко В.П. Основные проблемы историографии сибирского купечества и перспективы его дальнейшего изучения // Хозяйственное и культурное развитие Урала и Сибири в XIX-XXI вв. : сборник научных трудов. Вып. 5. Томск, 2014.

9. Рабинович Г.Х. Из истории торгового капитала в Сибири (А.Ф. и Н.А. Второвы) // Из истории Сибири. Выпуск четвертый. Томск, 1972.

10. Рабинович Г.Х. Из истории буржуазии в Сибири (Л.А. Михельсон) // Вопросы истории Сибири. Выпуск восьмой. Томск, 1974.

11. Рабинович Г.Х., Солопий Л.А. Крупная буржуазия Забайкалья (1895-1914 гг.). Статья первая // Из истории Сибири. Выпуск семнадцатый. Томск, 1975. 
12. Рабинович Г.Х., Скубневский В.А. Буржуазия в обрабатывающей промышленности Сибири (конец XIX в. - 1917 г.) // Из истории Сибири. Выпуск семнадцатый. Томск, 1975.

13. Рабинович Г.Х., Скубневский В.А. Буржуазия города Барнаула (середина 90-х годов XIX в. - 1914 г.) // Из истории Сибири. Выпуск третий. Томск, 1971.

14. Скубневский В.А. Города Сибири пореформенного времени в освещении современной советской историографии // Вопросы историографии и источниковедения Сибири периода капитализма. Томск, 1985.

15. Рабинович Г.Х. Монополизация речного судоходства в Сибири и на Дальнем Востоке (конец XIX в. 1917 г.) // Исторические записки. Т. 91. М., 1973.

16. Рабинович Г.Х. Городская недвижимость как сфера приложения капиталов буржуазии Сибири в конце XIX - начале XX вв. // Из истории Сибири. Выпуск третий. Томск, 1971.
17. Рабинович Г. Х. Крупная буржуазия и монополистический капитал в экономике Сибири конца XIX - начала XX в. : монография. Томск, 1975.

18. Разумов О.Н. Иностранный капитал в горной промышленности Сибири в период империализма : автореф. дис. ... канд. ист. наук. Томск, 1986.

19. Рабинович Г.Х. К характеристике состава финансовой олигархии в России // Исторический опыт хозяйственного освоения Сибири: тематический сборник статей / ред. коллегия: В.П. Зиновьев, О.Н. Разумов, Э.И. Черняк, В.А. Бузанова. Томск,1994.

20. Блинов Н.В., Рабинович Г.Х. Пролетариат и буржуазия Сибири в период империализма // Рабочий класс Центра страны и Сибири (конец XIX - начало XX в.). Новосибирск, 1981. 